\title{
マイクロステップ駆動を用いた リニアパルスモータの力制御
}

\begin{tabular}{|c|c|c|c|c|c|}
\hline 正員 & 真 & 田 & 雅 & 之 & （大阪府立大） \\
\hline & 森 & 本 & 茂 & 雄 & （大阪府立大） \\
\hline 正員 & 武 & 田 & 洋 & 人 & （大阪府立 \\
\hline
\end{tabular}

Thrust Control for Linear Pulse Motor using Micro-step Drive

Masayuki Sanada, Member, Shigeo Morimoto, Member, Yoji Takeda, Member (University of Osaka Prefecture)

キーワード：リニアパルスモータ、マイクロステップ駆動、力制御

\section{1. まえがき}

リニアパルスモータ（L P M）は機械的なリンク機構無 しに直接直線運動が可能であるので、高精度位置決め用ア クチュエータとして多くの利点を有している(1)(2)。また、 L PMは他のリニアモータと比䡸して小さい入力電力で大 きな推力が取り出せ、マイクロステップ駆動を用いること により非常に細かい変位動作が可能である。したがって、 L P Mを用いて簡単に力制御システムを構成することが可 能である。

本レターでは、マイクロステップ駆動を用いたL P M の 力制御システムを提案し、実験によりその妥当性について 検討を行なっている。

\section{2. マイクロステップ駆動を用いた力制御}

L P M の変位推力特性が正弦波状であると仮定すると、 マイクロステップ駆動時の発生推力 $F_{\mathrm{ms}}$ は、

$$
F_{\mathrm{ms}}=-k I_{\mathrm{R}} \sin (\theta-\mu)
$$

となる ${ }^{(3)}$ 。ここで、 $k$ はモー夕の推力定数、 $\theta$ は電気角で 表わした移動子位置、 $I_{\mathrm{R}}$ は電流の振幅、 $\mu$ はマイクロス テップ励磁電流の位相である。

マイクロステップ駆動では、図1(a)に示すように励磁電 流位相 $\mu$ を $\mu_{1} \rightarrow \mu_{2} \rightarrow \mu_{3}$ のように制御することにより、 $F_{\mathrm{ms}}=0$ となる安定点 $\theta=\mu$ に移動子位置を制御することが 可能となる。つぎに図 1 (b)に示すように、移動子が非常に 剛性の高い外部環境に接している場合を考える。励磁電流 位相を図 1 (a)の場合之同様に $\mu_{1} \rightarrow \mu_{2} \rightarrow \mu_{3}$ と変化させても 移動子がほとんど変位しなければ、図中 $a \rightarrow b \rightarrow c$ のよう に外部環境に対する接触力が電流位相にしたがって変化す る。これは、(1)式において励磁電流位相 $\mu$ の変化、すなわ ち $\theta-\mu$ の変化により、発生推力 $F_{\mathrm{ms}}$ を制御できるというこ とからもわかる。したがって、L PMのマイクロステップ 駆動を用いることで、移動子が対象物に接していない場合 は位置を、そして、対象物に接した後は接触力を制御する
ことが可能となる。

\section{3. 実験結果}

図 2 に実験システムの概略図を示す。外部環境への力は L PMの一端に設けられている力センサにより検出してい る。マイクロステップ電流位相の分割数は256であり、制御

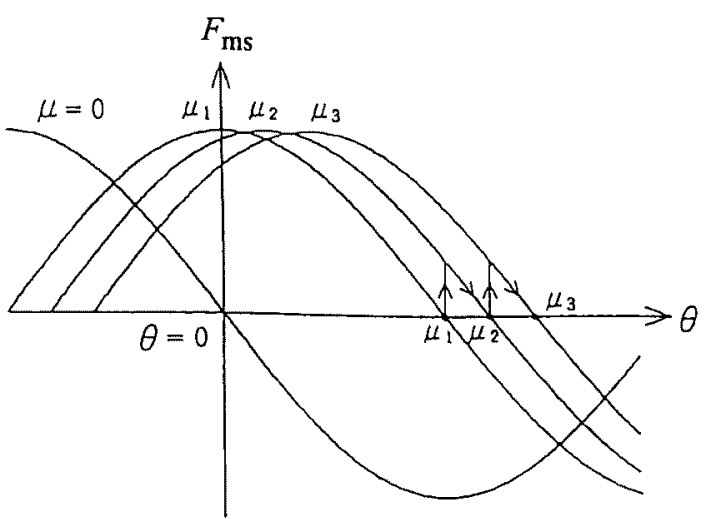

(a) 位置制御

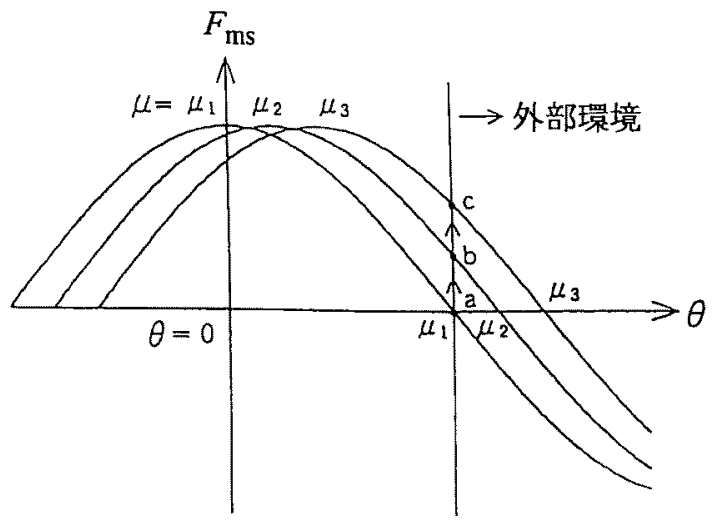

(b) 力制御

図 1 マイクロステップ駆動の概念図

Fig.1. Application of micro-step drive. 


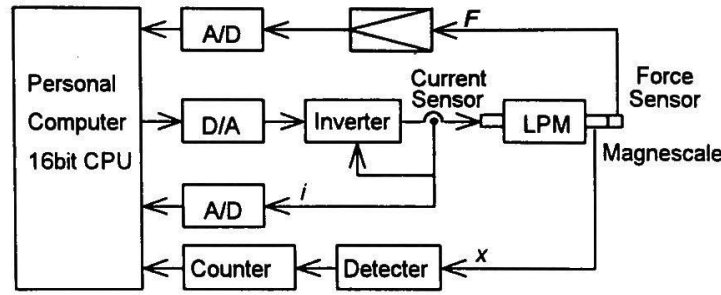

図 2 実験システム

Fig.2. Experimental system.

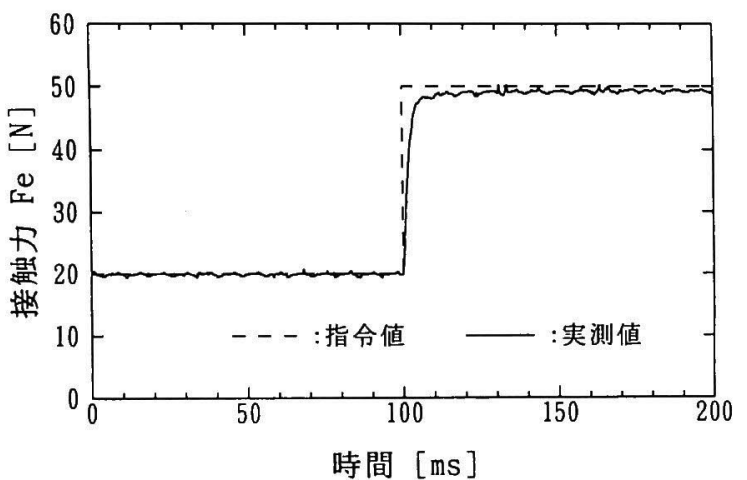

図 3 ステップ応答

Fig.3. Step response.

ループの実行時間は $0.4 \mathrm{~ms}$ である。図 3 は、P I 制御を用い た力制御システムのステップ応答である。力の指令值は時 刻100msで20Nから50Nにステップ変化させている。図3か ら接触力はかなり良好に制御されることがわかる。応答時

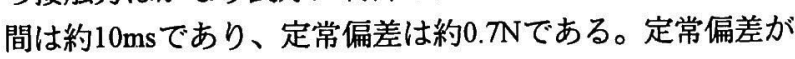
若干生じているが、これは L P Mのマイクロステップ駆動 時の位置決め分解能によるものである。これはマイクロス テップ電流位相の分割数を細かくして分解能を向上するこ とにより改善される。周波数特性を図 4 に示す。この力制 御システムは簡単な構成にもかかわらず良好な特性が得ら れ、約 $150 \mathrm{~Hz}$ まで低周波数領域と同等のゲインであるので、 このシステムの応答周波数は約 $150 \mathrm{~Hz}(-3 \mathrm{~dB})$ である。

\section{4. まとめ}

L P Mのマイクロステップ駆動を用いた簡単な力制御シ ステムを提案した。実験から、L P Mを用いた力制御シス テムは、簡単な構成にもかかわらずかなり速い応答を得る ことができた。本システムは高速鉄道用のアクティブパン タグラフや電子部品装着機等への応用が可能と考えられる。

(平成5年10月5日受付)

\section{文 献}

(1) 山田：リニアモータ応用ハンドブック, 工業調查会, pp. 312 327 (昭61)

(2) 海老原 他:「円筒状リニアパルスモータの位置決め精 度向上に関する検討」, 電学論 D, 111, 887 (平3-10)

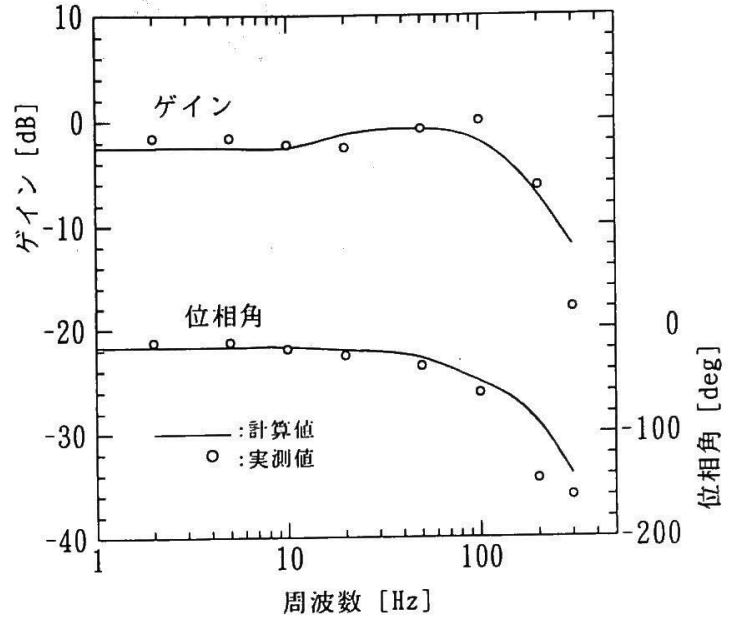

図 4 周.波数特性

Fig.4. Frequency characteristics.

(3) 高木・真田 他：「L P M 用いた力制御におけるパラ メー夕変化の影響」, 平 5 電学産応全大, No. 143

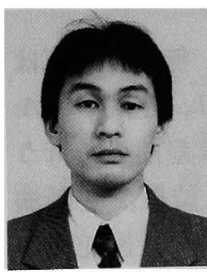

\section{真 田 雅之（正員）}

昭和 41 年6月1日生。平成3年3月大阪府立 大学大学院工学研究科電気工学修士課程修 了。同年4月同研究科博士課程進学、現在 に至る。この間、主としてリニアモータの 研究に従事。パワーエレクトロニクス研究会学生員。

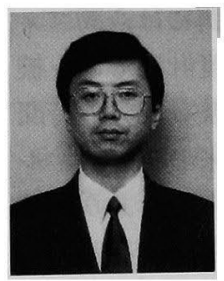

\section{森 本 茂 雄 (正員)}

昭和34年6月28日生。59年3月大阪府立大 学大学院工学研究科電気工学修士課程修了。 同年4月三菱電機（株）入社。63年7月大阪 府立大学工学部助手、平成5年7月同講師、 現在に至る。工学博士。この間、主としてインバータシス テム、ACサーボ制御システムの研究に従事。IEEE、計測 自動制御学会、パワーエレクトロニクス研究会会員。

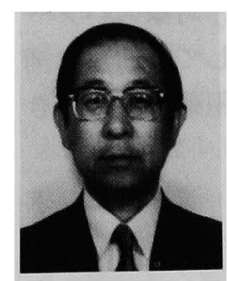

\section{武 田 洋 次 (正員)}

昭和18年11月10日生。43年3月大阪府立 大学大学院工学研究科電気工学修士課程修 了。同年4月同大学工学部助手、62年4月同 講師、平成2年7月同助教授、5年4月同教授、 現在に至る。工学博士。この間、主として電動機の可変速 制御システム、D D 用アクチュエータならびにリニアモー 夕の研究に従事。IEEE、システム制御情報学会、パワーエ レクトロニクス研究会会員。 